\title{
Geographic pattern of morphological variation of the coconut mite, Aceria guerreronis Keifer (Acari: Eriophyidae), using multivariate morphometry
}

\author{
Navia, D. ${ }^{\mathrm{a}}$, Moraes, GJ. ${ }^{\mathrm{b}}$ and Querino, RB. ${ }^{\mathrm{c}}$ \\ anúcleo Temático em Segurança Biológica, Embrapa Recursos Genéticos e Biotecnologia, \\ Parque Estação Biológica s/n, Asa Norte, CP 02372, CEP 70770-900, Brasilia, DF, Brazil

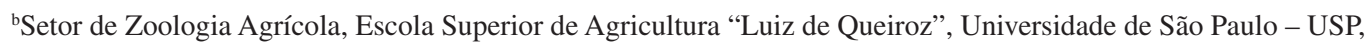 \\ Av. Pádua Dias 11, CP 09, CEP 13418-900, Piracicaba, SP, Brazil \\ ${ }^{\mathrm{c}}$ Empresa Brasileira de Pesquisa Agropecuária - Embrapa Meio Norte \\ Av. Duque de Caxias, 5650, Bairro Buenos Aires, CP 001, CEP 64006-220, Teresina, PI, Brazil \\ *e-mail navia@ cenargen.embrapa.br
}

Received August 27, 2007 - Accepted January 24, 2008 - Distributed August 31, 2009

(With 13 figures)

\begin{abstract}
The coconut mite, Aceria guerreronis Keifer, has become one of the most important pests of coconut in the Americas and Africa and recently in Southeast Asia. Despite the great economic importance of this mite, there is a lack of information on its origin and invasion history that are important to guide the search of biological control agents as well as the adoption of quarantine procedures. This study evaluates morphometric variation among A. guerreronis populations throughout its occurrence area, relates this variation with historical sequence of records, looking for information on its biogeography. Samples of 27 populations from the Americas, Africa and Asia were analysed using Principal Component Analysis and Canonical Discriminant Analysis. Results showed significant morphometric variability of A. uerreronis throughout its distribution area, with a high variability among American populations and otherwise a high similarity among African and Asian populations. The geographic pattern of variation of mite populations observed supports the hypothesis that A. guerreronis originated in the Americas and was introduced into Africa and Asia. Some inferences related to taxonomy of Eriophyoidea mites were included.
\end{abstract}

Keywords: principal component analysis, canonical discriminant analysis, exotic invasive species, Cocos nucifera, biogeography.

\section{Padrão geográfico de variação morfológica do ácaro do coqueiro, Aceria guerreronis Keifer (Acari: Eriophyidae), utilizando morfometria multivariada}

\begin{abstract}
Resumo
O ácaro do coqueiro, Aceria guerreronis Keifer, se tornou uma das pragas mais importantes do coqueiro nas Américas e África e, recentemente, no sudeste da Ásia. Apesar da importância econômica deste ácaro, faltam informações sobre sua origem e seu histórico de invasão, o que é importante para orientar a busca de agentes de controle biológico assim como a adoção de medidas quarentenárias. Este estudo teve como objetivo avaliar a variação morfométrica entre populações de A. guerreronis ao longo de sua área de ocorrência, relacionar esta variação com a sequência histórica de registros, buscando informações sobre sua biogeografia. Amostras de 27 populações das Américas, África e Ásia foram analisadas utilizando-se Análise dos Componentes Principais e Análise Discriminante Canônica. Os resultados mostraram uma significante variabilidade de A. guerreronis ao longo de sua área de distribuição, com uma alta variabilidade entre as populações americanas e, por outro lado, uma alta similaridade entre populações africanas e asiáticas. O padrão geográfico de variação de populações do ácaro observado suporta a hipótese de que A. guerreronis é originário da América e foi introduzido na África e Ásia. Algumas inferências relacionadas à taxonomia de ácaros Eriophyoidea foram incluídas.
\end{abstract}

Palavras-chave: análise dos componentes principais, análise discriminante canônica, espécie invasora exótica, Cocos nucifera, biogeografia. 


\section{Introduction}

The coconut mite, Aceria guerreronis Keifer (Acari: Eriophydae), is an invasive mite pest that has been disseminated and established rapidly in main coconut (Cocos nucifera L.) production areas. Mite infestation causes reductions in copra yield, extensive premature dropping of coconuts (Moore and Howard, 1996), as well as value depreciation of green nuts on the coconut water market.

The species was first described by Keifer (1965) from specimens from Guerrero, Mexico. However some collection records indicate that it was already present in South-America (Robbs and Peracchi, 1965; Doreste, 1968; Zuluaga and Sánchez, 1971). Almost simultaneously with its original description, the mite was reported in Africa (Cabral and Carmona, 1969; Mariau, 1969). The most recent records of the coconut mite were from Asia, from India and Sri Lanka, where the species was unknown until the end of the 1990s (Sathiamma et al., 1998; Fernando et al., 2002). Surprisingly, the mite has never been reported in the presumed region of coconut origin, namely, extreme South-East Asia to Papua New Guinea (Persley, 1992; Lebrun et al., 1998).
Despite the great economic importance of the coconut mite, there is a lack of information on basic aspects. The place of origin of the coconut mite and the sources of recent invasions are unknown. The major perspectives for management and control of $A$. guerreronis involve the utilisation of biological control agents and the knowledge about its origin place which are important to determine priority areas to be considered in the search for effective enemies (Moraes and Zacarias, 2002). Information on the sources of A. guerreronis invading new areas can guide adoption of quarantine measures.

Studies of morphological and genetic variability among A. guerreronis populations from different countries and continents can provide some of the required information. Multivariate morphometry is a useful tool in evolutive biology to test historic phylogenetic hypotheses, to detect variation in quantitative characters and to evaluate patterns of phenetic relationship (Reis, 1988). It may also provide feedback information on expected characters variability within and between populations and contribute to the taxonomic knowledge of the studied group.

The present study intended to answer two main questions: 1) Is there morphological variation of taxonomic

Table 1. Sampling localities of Aceria guerreronis populations. Code and number of measured females.

\begin{tabular}{|c|c|c|c|c|}
\hline Continent & Country & Locality & Code & $\begin{array}{c}\text { Number of } \\
\text { females }\end{array}$ \\
\hline \multirow[t]{3}{*}{ Africa } & Benin & Ipinkle & $\mathrm{a}$ & 15 \\
\hline & & Ouidah & $\mathrm{b}$ & 15 \\
\hline & Tanzania & Micuranga & $\mathrm{c}$ & 15 \\
\hline \multirow[t]{14}{*}{ America } & Brazil & Aracaju, Sergipe & $\mathrm{d}$ & 15 \\
\hline & & Ilha Bela, São Paulo & $\mathrm{e}$ & 15 \\
\hline & & Ilhéus, Bahia & $\mathrm{f}$ & 10 \\
\hline & & Janaúba, Minas Gerais & $\mathrm{g}$ & 15 \\
\hline & & Lagarto, Sergipe & $\mathrm{h}$ & 15 \\
\hline & & Maceió, Alagoas & $\mathrm{i}$ & 15 \\
\hline & & Petrolina, Pernambuco & $\mathrm{j}$ & 15 \\
\hline & & Quissamã, Rio de Janeiro & $\mathrm{k}$ & 15 \\
\hline & & Recife, Pernambuco & $\mathrm{L}$ & 15 \\
\hline & & São Felix, Bahia & $\mathrm{m}$ & 15 \\
\hline & Cuba & Habana & $\mathrm{n}$ & 15 \\
\hline & Mexico & Guerrero & o & 5 \\
\hline & USA & San Diego, California* & $\mathrm{p}$ & 15 \\
\hline & Venezuela & Zulia & $\mathrm{q}$ & 13 \\
\hline \multirow[t]{10}{*}{ Asia } & India & Kasaragod, Kerala & $\mathrm{r}$ & 15 \\
\hline & & Kayankulam, Kerala & $\mathrm{s}$ & 15 \\
\hline & & Vellanikara, Kerala & $\mathrm{t}$ & 15 \\
\hline & Sri Lanka & Hingurakgoda & $\mathrm{u}$ & 15 \\
\hline & & Kalpitiya & $\mathrm{v}$ & 15 \\
\hline & & Laksha Uyana & $\mathrm{w}$ & 15 \\
\hline & & Madampe & $\mathrm{x}$ & 15 \\
\hline & & Madurankuliya & $\mathrm{y}$ & 15 \\
\hline & & Unagala Vehera & $\mathrm{z}$ & 15 \\
\hline & & Wanathawilluwa & $\mathrm{I}$ & 15 \\
\hline
\end{tabular}

*from developing tips of Syagrus romanzoffiana. 
traits of samples of A. guerreronis throughout its distribution areas in Africa, Americas and Asia? 2) Is there a geographic pattern of morphological variation among populations of $A$. guerreronis?

\section{Material and Methods}

\subsection{Samples}

About 50 mites of each of 27 A. guerreronis populations from 9 countries in Africa (Benin, Tanzania), America (Brazil, Cuba, Mexico, USA and Venezuela), and Asia (India and Sri Lanka) were used in this study. Collection localities are shown in Table 1. All populations were collected from coconut fruits except the one from San Diego, California, USA, collected from developing tips of young Queen Palm, S. romanzoffiana. Mites collected were preserved in $70 \%$ ethyl alcohol (no longer than 2 months) and mounted on slides using modified Berlese medium. Adult females were used in all morphometric analyses. The fifteen best mounted females of each population were selected for the evaluations, except for mites from Guerrero, Mexico (5 specimens); Zulia, Venezuela (13) and Ilhéus, Bahia, Brazil (10).

\subsection{Morphological evaluations}

Fifty-six characters were evaluated on each sampling mite using a phase-contrast microscope (Leica DMLS) (100× objective) (Figure 1). The characters evaluated were those commonly used and considered important in Eriophyoidea systematics (Amrine Jr. et al., 1994; Huang et al., 1996). When a clear difference in lengths was observed between right and left homologue of a same structure in the same specimen, only the longer was considered. When homologous ventral setae were inserted in different annuli, they were considered to be inserted on the anterior one.

\subsection{Multivariate procedures}

Two multivariate statistical procedures were applied to the data: the princomp procedure performs Principal Component Analysis (PCA) and the candisc procedure performs a Canonical Discriminant Analysis (CDA), both statistical analyses were conducted using procedures of SAS (SAS Institute, 1990). The main characters responsible by this ordination were the ones that have presented the ten eigenvectors with highest absolute value. Analyses were done using log transformations of the raw data. The logarithmic transformation preserves allometries, standardises variances and produces a scale-invariant covariance matrix (Bookstein et al., 1985). Populations of different geographical regions were compared by pooling them in different combinations: 1) Brazil; 2) America (including Brazil); 3) America and Africa; 4) America and Asia; 5) Africa and Asia; 6) America, Africa and Asia. Analyses of these combinations allowed the better understanding of the morphological relationship among populations of the different continents.

\section{Results}

Multivariate analysis applied (PCA and CDA) showed morphological variation among populations of A. guerreronis from sampled localities. CDA showed that the canonical axes were significant for all combinations of populations.

\subsection{Brazil}

PCA showed that the first two principal components (PRIN1 and 2) jointly explained 33\% of the total variation among the Brazilian populations, the first explaining 22.7 and the second $10.3 \%$ of the variation. When plotted against their respective values for PRIN1 and PRIN2 (Figure 2), mites of some populations [Aracaju (d), Janaúba (g), Petrolina (j) Quissamã (k) and São Felix (m)] were scattered along both axes, indicating a considerable morphometric variability within each of them. Differently, mites from other populations [Ilhéus (f), Maceió (i) and Recife (L)] were each concentrated in a relatively small area of the graphic, indicating higher morphometric similarity within each of them. São Felix (m) population most differed from others, especially along the PRIN1 axis.

The first two canonical variables (CAN1 and 2) jointly explained $60.8 \%$ of the total variation, the first explaining 42 and the second $18.8 \%$ of the variation. CDA also showed considerable variability among the Brazilian populations, which were separated in four groups (Figure 3): 1) Ilha Bela (e); 2) Maceió (i); 3) Aracaju (d); 4) São Felix (m), Ilhéus (f), Janaúba (g), Lagarto (h), Petrolina (j), Quissamã (k), and Recife (L). The ordination graphic of all the populations of group 4 indicated considerable morphometric similarities. The main characters responsible by this ordination referred to: the prodorsal shield (scapular setae length); coxigenital region (setae length), opisthosoma (setae length; number of dorsal and ventral rings; space and number of microtubercles between ventral setae) and leg (setae and segment length).

Morphometric proximity between populations not always corresponded to the respective geographic proximity. Populations from relatively close sites, in northeastern Brazil, for example, from Aracaju in relation to Lagarto, both placed in the same State, belonged to different groups, whereas populations from distant sites in northeastern (Petrolina and Recife) and southeastern Brazil (Janaúba and, Quissamã) belonged to the same group. In Brazilian populations a large morphometric variation was observed.

\subsection{America}

PCA showed that the first two principal components jointly explained $35.4 \%$ of the total variation among the American populations, the first explaining 22.9 and the second $12.5 \%$ of the variation. When plotted against their respective values for PRIN1 and PRIN2 (Figure 4), mites of most Brazilian populations (d-L) were scattered along PRIN1 axis, overlapping each other but partially sepa- 


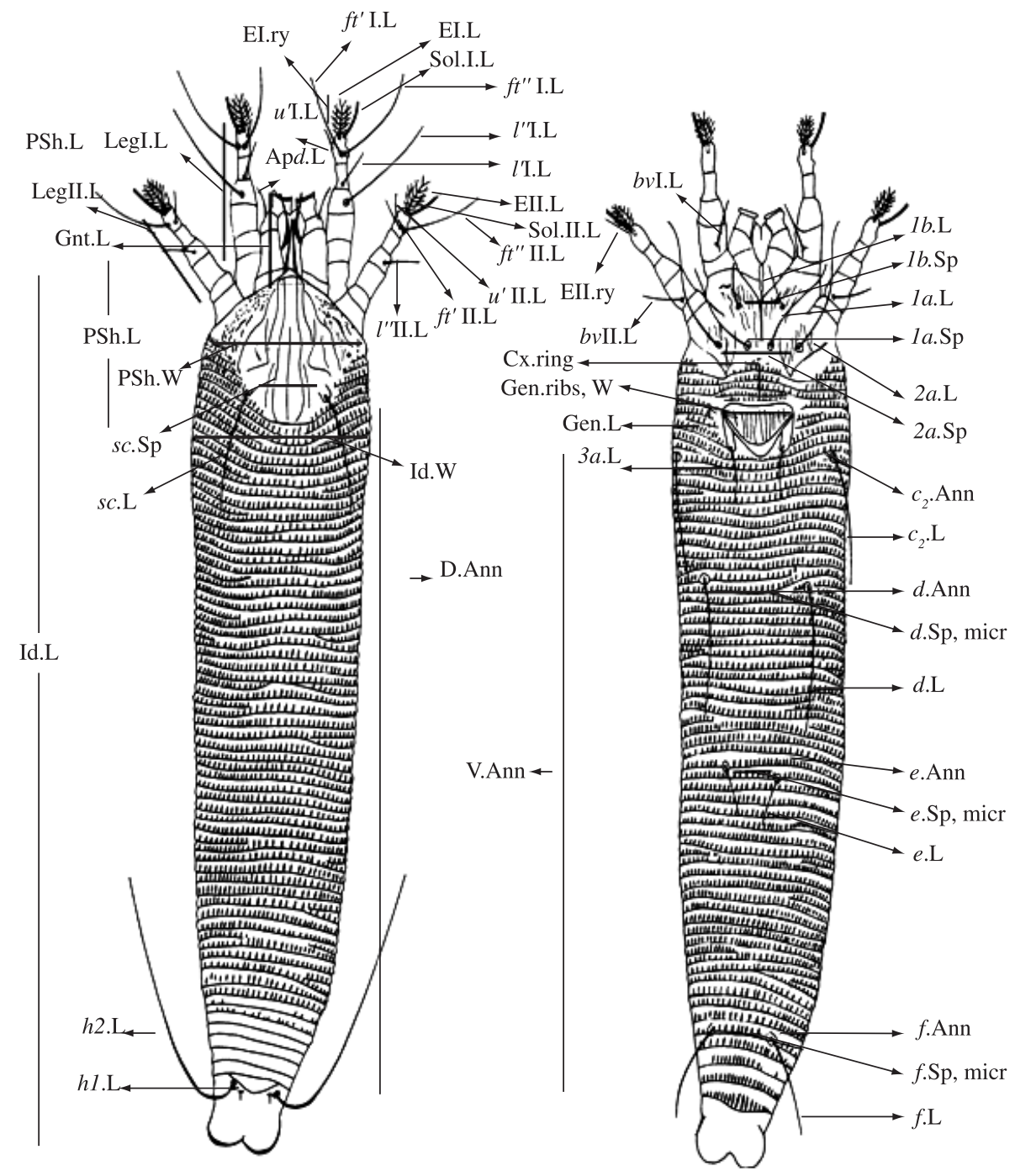

Figure 1. Measurements of A. guerreronis female used in the statistical analysis. Id.L - idiosoma length; Id.W - idiosoma width; Gnt.L - gnathosoma length; Apd.L - antapical seta length; Psh.L - prodorsal shield length; PSh.W - prodorsal shield weight; sc.L - scapular seta length; sc.Sp - space between tubercles bearing scapular setae; Leg.I.L - leg I length; bvI.L femoral seta I length; 1' I.L - genual seta I length; 1'I.L - tibial seta I length; ft' 'I.L - lateral seta I length; ft'I.L - dorsal seta I length; u'I.L - unguinal seta I length; SolI.L - solenidion I length; EI.L - empodium I length; EI.ry - number of empodium I rays; LegII.L - leg II length; bvII.L - femoral seta II length; 1'II.L - genual seta II length; ft' II.L - lateral seta II length; ft'II.L - dorsal seta II length; u'II.L - unguinal seta II length; SolII.L - solenidion II length; EII.L - empodium II length; EII. ry - number of empodium II rays; 1b.L - coxal seta I length; 1b.Sp - space between coxal setae I; 1a.L - coxal seta II length; 1a.Sp - space between coxal setae II; 2a.L - coxal seta III length; 2a.Sp - space between coxal setae III; Cx.N - number of coxigenital rings; Gen.L - genitalia length; Gen.W - genitalia width; Gen. R - number of genital longitudinal ribs; 3a.L genital seta length; c2.L - lateral seta length; c2.Ann - lateral seta annuli; d.L - ventral seta I length; d.Ann - ventral seta I annuli; d.Sp - space between ventral setae I; d.micr - number of microtubercles between ventral seta I; e.L - ventral seta II length; e.Ann - ventral seta II annuli; e.Sp - space between ventral setae II; e.micr - number of microtubercles between ventral seta II; f.L - ventral seta III length; f.Ann - ventral seta III annuli; f.Sp - space between ventral setae III; f.micr - number of microtubercles between ventral seta III; D.Ann - number of dorsal annulus; V.Ann - number of ventral annulus; h2.L caudal seta length; h1.L - accessory seta length. 


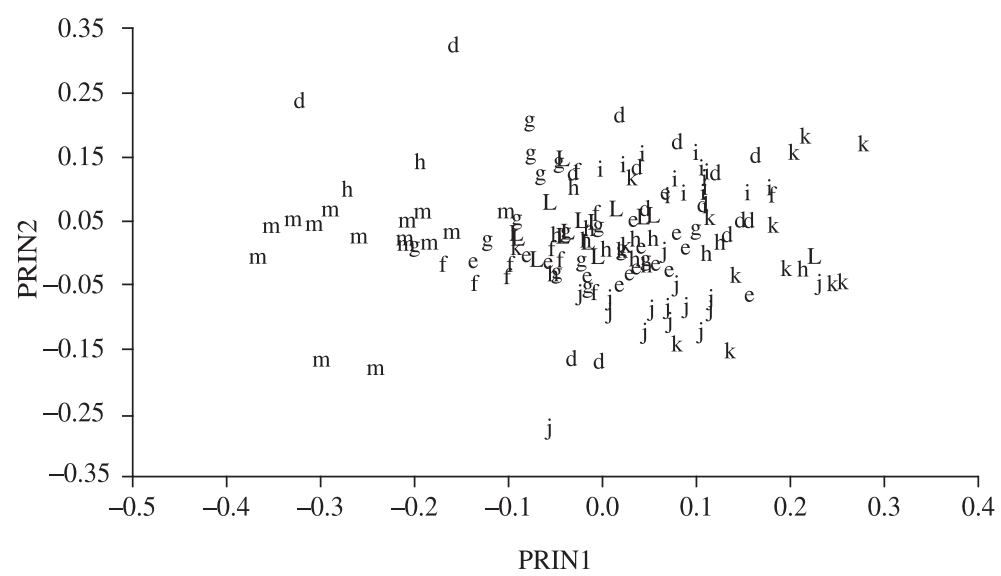

Figure 2. Principal Component Analysis of Brazilian populations of A. guerreronis. Individuals plotted against their values for the first two principal components. Letters represent collection sites specified in Table 1.

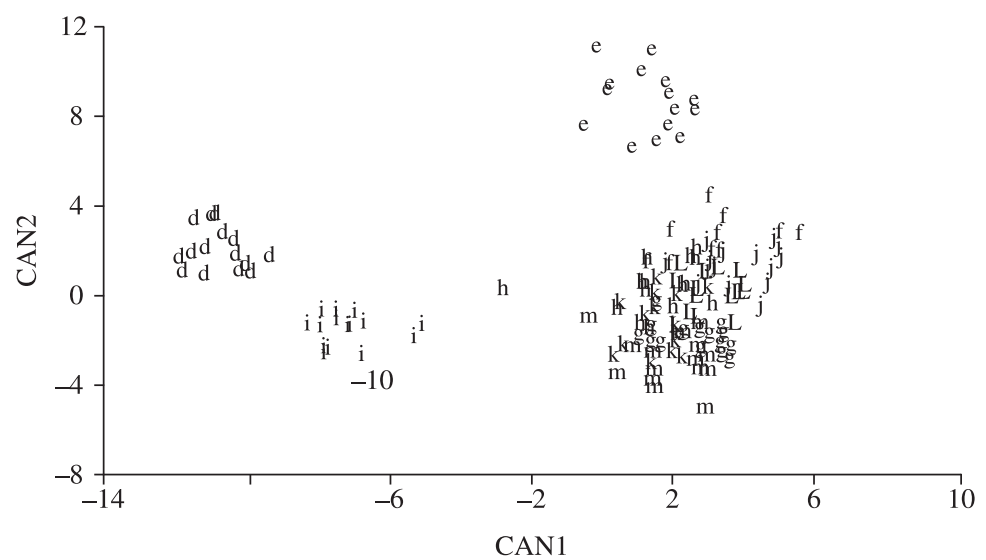

Figure 3. Canonical Discriminant Analysis of Brazilian populations of A. guerreronis. Individuals plotted against their values for the first two canonical variables. Letters represent collection sites specified in Table 1.

rated from the populations of other American countries [Havana (n), Guerrero (o), California (p) and Zulia (q)] along PRIN2 axis (Figure 4). The non-Brazilian populations overlapped along the PRIN1 axis.

The first two canonical variables jointly explained $51.2 \%$ of the total variation, the first explaining 29.5, the second $21.7 \%$ of the variation. American populations formed three main groups (Figure 5): 1) Aracaju (d) and Maceió (i); 2) Ilha Bela (e), Ilhéus (f), Janaúba (g), Lagarto (h), Petrolina (j), Quissamã (k) and Recife (L) and São Felix (m), all from Brazil; 3) other nonBrazilian populations (n-q). Group 1 differed most from group 2, both with Brazilian populations, along CAN1 axis. The main characters responsible by this ordination referred to: legs (segment or setae lengths), prodorsal shield (scapular setae length), and opisthosoma (position of ventral setae; number of ventral rings and setae length).

At this larger scale, that is, when populations from several American countries were analysed together, a dis- tinct morphometric geographical pattern was observed in both PCA and CDA. Populations from closer sites were generally more similar. The majority of the Brazilian populations were separated of populations from the Caribbean (Havana) and North America (California and Guerrero) populations.

\subsection{America and Africa}

PCA showed that the first two principal components jointly explained $41.8 \%$ of the total variation among the American and African populations, the first explaining 31.4 and the second $10.4 \%$ of the variation. When plotted against their respective values for PRIN1 and PRIN2, the American populations were partially separated from the African populations along the PRIN1 axis (Figure 6). Populations of Havana (n), Guerrero (o), California (p), Zulia (q) and São Felix (m) were graphically intermediate between African and Brazilian populations.

The first two canonical variables jointly explained $45.1 \%$ of the total variation, the first explaining 23.6 
and the second $21.5 \%$ of the variation. Populations of both continents were separated in four main groups (Figure 7): 1) The non-Brazilian American populations (n-q); 2) Two Brazilian populations (d and i); 3) Other Brazilian populations (e, f, g, h, j, k, L, m) and 4) The African populations (a-c). The ordination of popula-
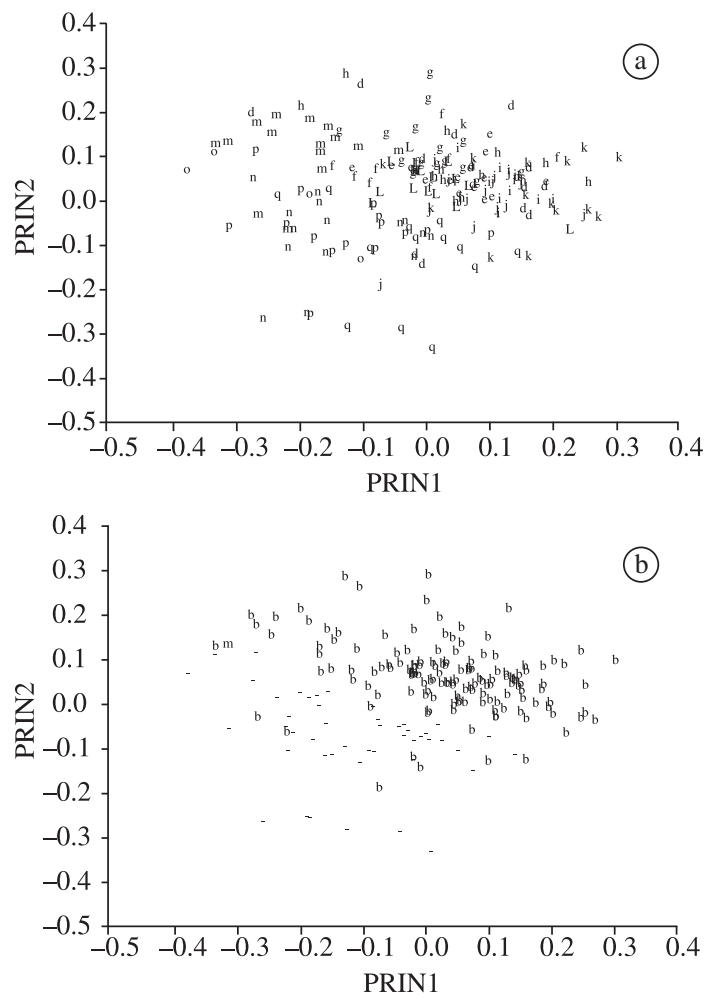

Figure 4. Principal Component Analysis of American populations of A. guerreronis. Individuals plotted against their values for the two first principal components. a) letters represent collection sites specified in Table 1. b) signs represent: b) Brazilian and (-) other American populations. tions from Africa and America was mainly determined by characters of legs (segment or setae lengths) and opisthossoma (setae length and their position; number of dorsal and ventral rings). Also, a distinct morphometric geographical pattern was observed in both PCA and CDA for Brazilian, non-Brazilian American and African populations, at this scale.
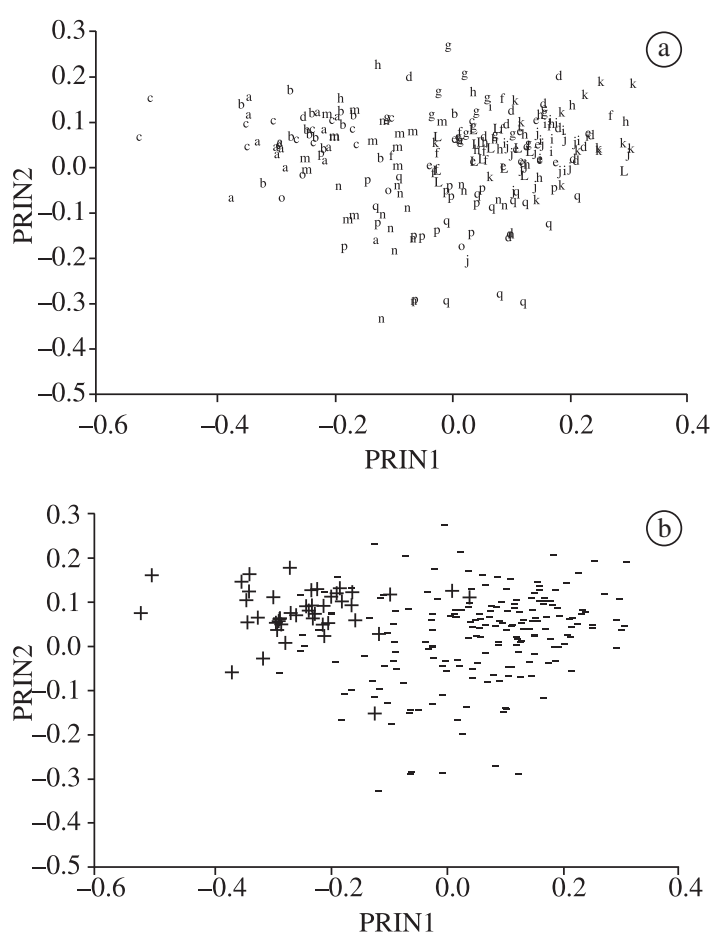

Figure 6. Principal Component Analysis of American and African populations of A. guerreronis. Individuals plotted against their values for the two first principal components. a) letters represent collection sites specified in Table 1 . b) signs represent: (-) American and (+) African populations.

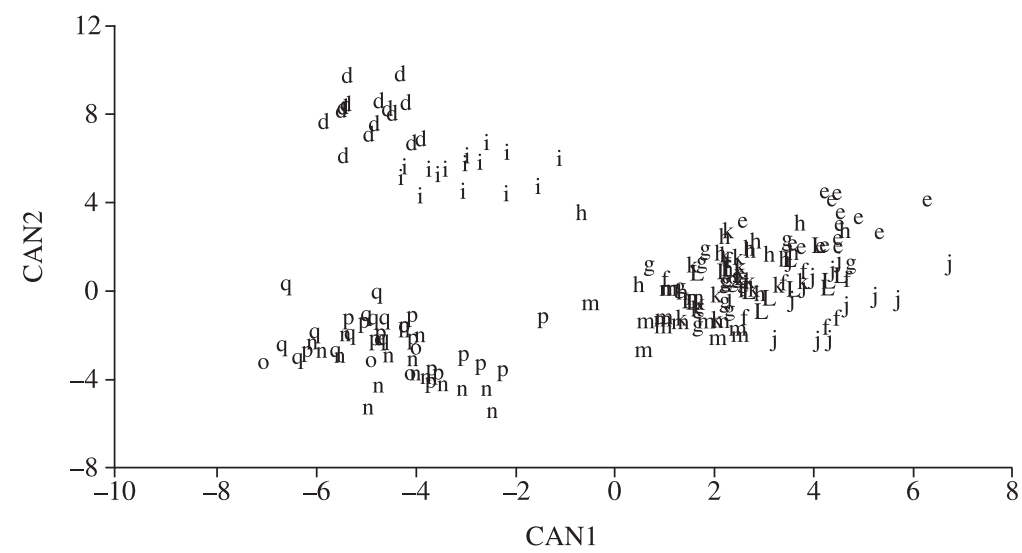

Figure 5. Canonical Discriminant Analysis of American populations of A. guerreronis: Individuals plotted against their values for the two first canonical variables. a) letters represent collection sites specified in Table 1. b) signs represent: b) Brazilian and (-) other American populations. 

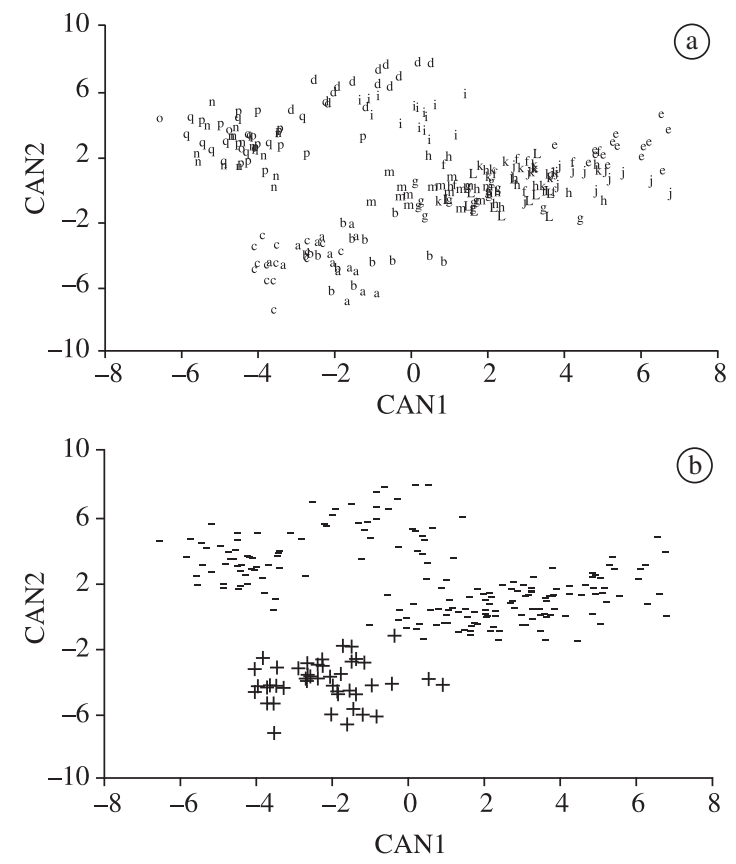

Figure 7. Canonical Discriminant Analysis of American and African populations of A. guerreronis. Individuals plotted against their values for the first two canonical variables. a) letters represent collection sites specified in Table 1. b) signs represent: (-) American and (+) African populations.
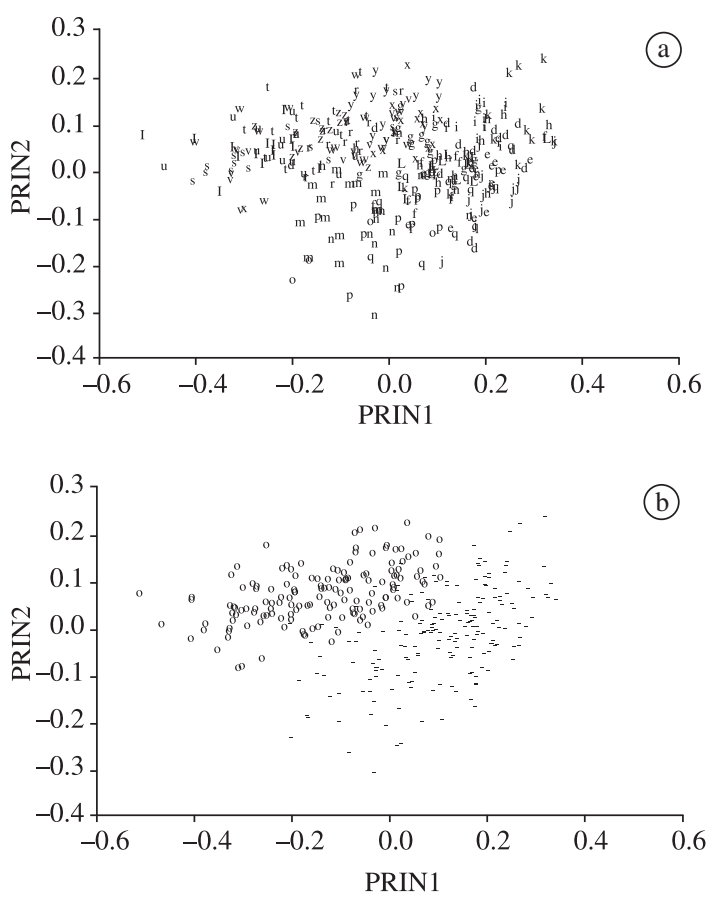

Figure 8. Principal Component Analysis of American and Asian populations of A. guerreronis. Individuals plotted against their values for the first two canonical variables. a) letters represent collection sites specified in Table 1 . b) signs represent: (-) American and (o) Asian populations.

\subsection{America and Asia}

PCA showed that the first two principal components jointly explained $42.1 \%$ of the total variation among the American and Asian populations, the first explaining 33 and the second $9.1 \%$ of the variation. When plotted against their respective values for PRIN1 and PRIN2 (Figure 8), American populations (d-q) were partially separated from Asian populations mainly along PRIN1.

The first two canonical variables jointly explained $51.1 \%$ of the total variation, the first explaining 35.1 and the second $16 \%$ of the variation. Populations of both continents were separated in three main groups (Figure 9): 1) The Asian populations (r-z, I); 2) The Brazilian populations (d-m) and; 3) The non-Brazilian American populations (n-q). Asian populations were completely separated from the American populations along CAN1 axis. The main characters responsible for this ordination referred to the opisthosoma (number of ventral and dorsal rings; position and number of microtubercles between ventral setae; setae length) and legs (segment or setae lengths). The morphometric geographical pattern was clearly distinct in either PCA or CDA for Asian and American populations.

\subsection{Africa and Asia}

PCA showed that the first two principal components jointly explained $38 \%$ of the total variation among
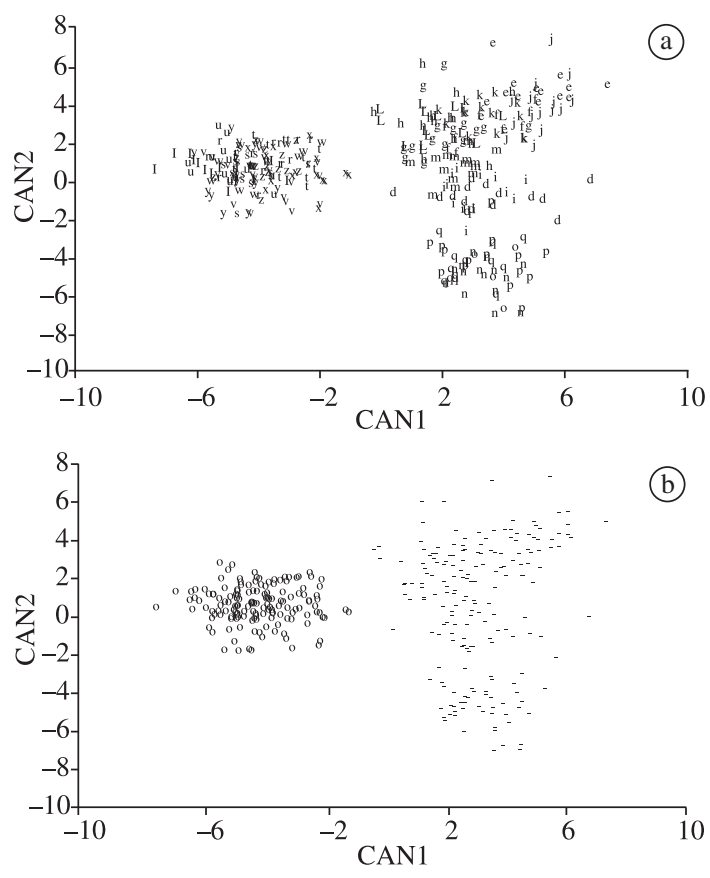

Figure 9. Canonical Discriminant Analysis of American and Asian populations of A. guerreronis. Individuals plotted against their values for the first two canonical variables. a) letters represent collection sites specified in Table 1. b) signs represent: (-) American and (o) Asian populations. 
the African and Asian populations, the first explaining 31 and the second $7 \%$ of the variation. When plotted against their respective values for PRIN1 and PRIN2 (Figure 10), the graphic ordination of the African population overlapped those of the Asian populations and discrimination among them was not observed.

The first two canonical variables jointly explained $42.9 \%$ of the total variation, the first explaining 26.2 and the second $16.7 \%$ of the variation. Populations of both continents were partially overlapped and not formed well-defined groups (Figure 11). Those results indicated a morphometric similarity among populations of both continents. Morphometric geographical pattern was not observed in this case.

\subsection{America, Africa and Asia}

PCA showed that the first two principal components jointly explained $43.5 \%$ of the total variation among all the populations considered in this study (American, African and Asian populations); the first explained 34.9 and the second 8.6 of the variation. When plotted against their respective values for PRIN1 and PRIN2 (Figure 12), the African populations (a-c) overlapped widely the Asian populations (r-z, I), and both were partially separated from the American population (d-q). Brazilian populations were mainly distinguished from African and Asian along the PRIN1 axis, while non-Bra-
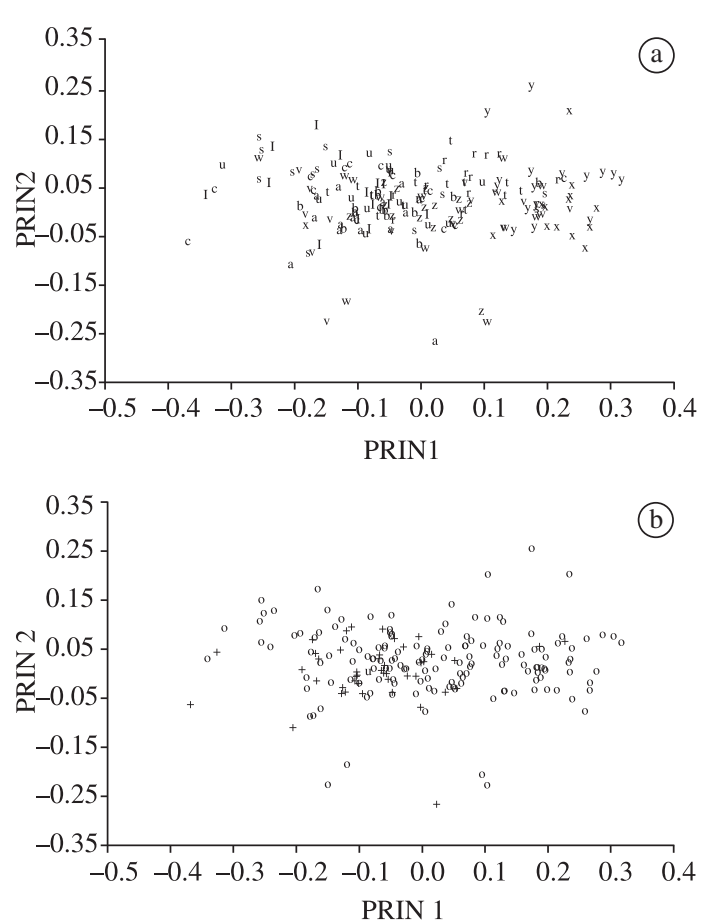

Figure 10. Principal Component Analysis of African and Asian populations of A. guerreronis. Individuals plotted against their values for the first two canonical variables. a) letters represent collection sites specified in Table 1 . b) signs represent: (+) African and (o) Asian populations. zilian American populations were mainly distinguished along the PRIN2 axis (Figure 12).

The first two canonical variables jointly explained $49.3 \%$ of the total variation, the first explaining 34.5 and the second $14.8 \%$ of the variation. Populations of all continents were separated in three main groups (Figure 13): 1) The Brazilian populations (d-m); 2) The African (a-c) and Asian (r-z, I) populations; and 3) The non-Brazilian American populations (n-q).

Populations from Asia and Africa were distinguished from the American mainly along the CAN1 axis. Thus, the main characters that discriminated the populations of those continents referred to the opisthosoma (numbers of dorsal and ventral rings, distance and number of microtubercles between ventral setae and setae length). Non-Brazilian American populations were distinguished from all other populations mainly along the CAN2 axis. Thus, the main characters that discriminated these populations were related to legs (leg and setae lengths). Morphometric geographical pattern was only partially distinct in this case.

All Brazilian populations were separated of nonBrazilian American populations, forming a different group. On the other hand, populations from two widely separate continents, Africa and Asia were grouped.
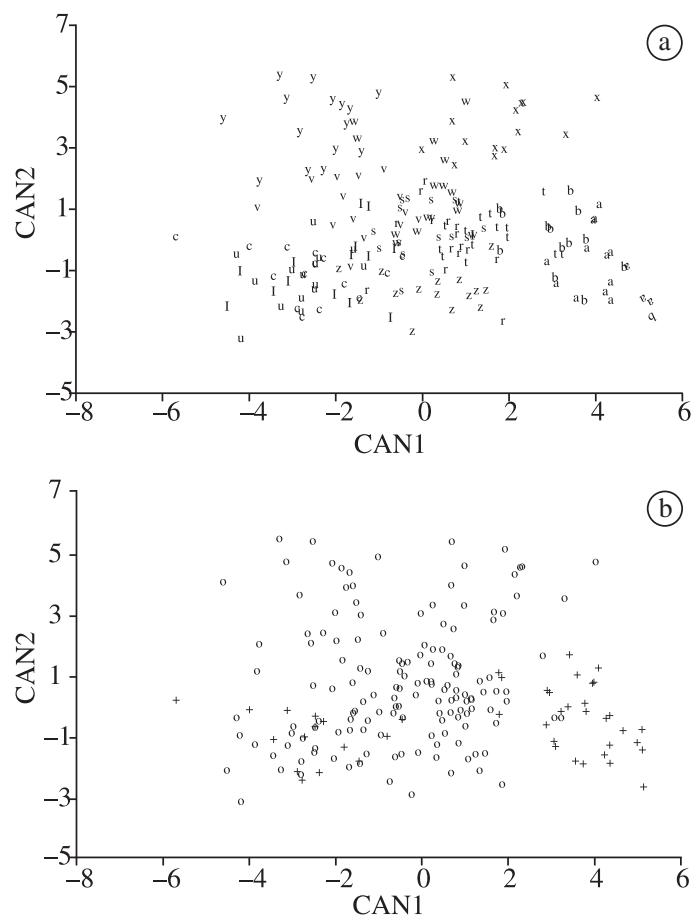

Figure 11. Canonical Discriminant Analysis of African and Asian populations of A. guerreronis. Individuals plotted against their values for the first two canonical variables. a) letters represent collection sites specified in Table 1 . b) signs represent: (+) African and (o) Asian populations. 

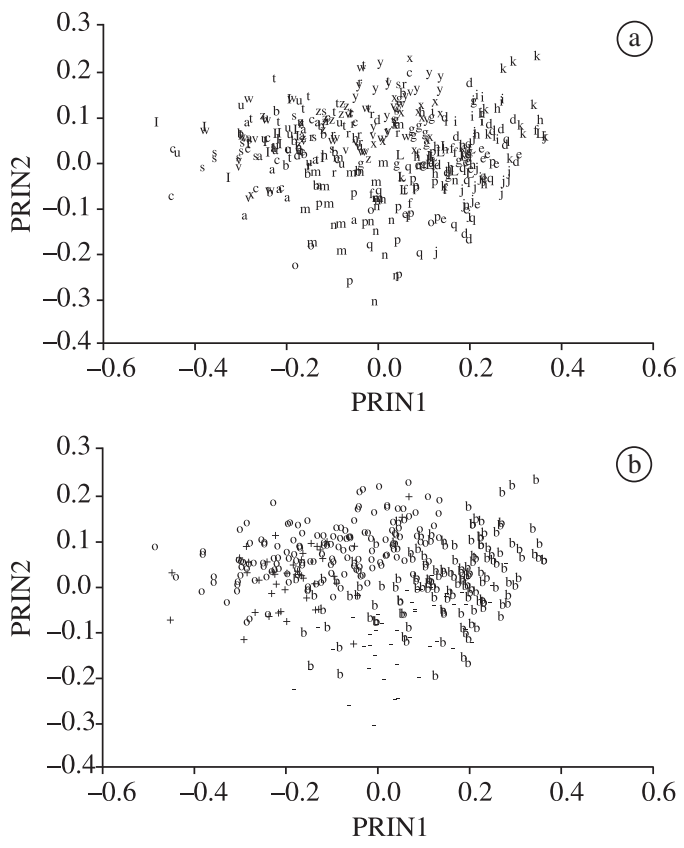

Figure 12. Principal Component Analysis of American, African and Asian populations of A. guerreronis. Individuals plotted against their values for the first two canonical variables. a) letters represent collection sites specified in Table 1. b) signs represent: (b) Brazilian; (-) other American; (+) African and (o) Asian populations.

\section{Discussion}

In general, similar patterns were obtained by both PCA and CDA analysis for all combinations of populations from the different geographical regions. They clearly showed the variability of A. guerreronis over its geographic distribution.

Phenotypic variation of mite populations on different hosts was ascribed by Skoracka et al. (2002) to causes which could be interpreted either as an intrinsic characteristic of the population and would refer to its phenotypic plasticity; or an acquired condition and would be related to genetic separation. It is expected that morphological variation between A. guerreronis populations from $S$. romanzoffiana living on coconut hosts in different geographic regions could also be attributed to any of those causes. Sometimes, the morphometric analyses indicate that the environmental conditions are not the main determining factors determining variability. For instance, some neighboring Brazilian populations from climatically rather similar areas, as are those from the northeastern coastal region, did show very pronounced differences, which strongly support that the observed morphological variability of such populations are closely related to the genetic characteristics of the species.

The absence of a distinct geographic pattern of morphometric variation when the Brazilian populations were analysed by themselves and the high morphometric vari-
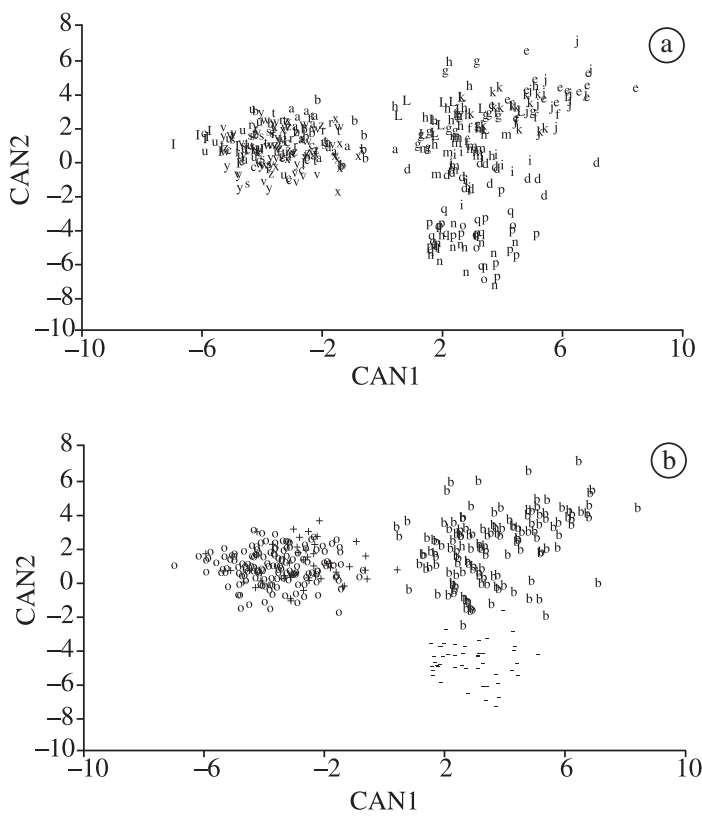

Figure 13. Canonical Discriminant Analysis of American, African and Asian populations of A. guerreronis. Individuals plotted against their values for the first two canonical variables. a) Letters represent collection sites specified in Table 1. b) signs represent: (b) Brazilian; (-) other American; (+) African and (o) Asian populations.

ability suggests a high genetic diversity of those populations. On the other hand, the absence of a distinct geographic pattern of morphometric variation when Africa and Asia populations were jointly considered and the similarity between the African and the Asian populations indicate their close genetic characteristics. Results of morphometric analyses are in compliance with those obtained through molecular analyses, using nuclear ribosomal internal transcribed spacer (ITS) and mitochondrial $16 \mathrm{~S}$ ribosomal (16S) sequences, conducted by Navia et al. (2005), using specimens from the same populations used in the present study.

The place of origin of A. guerreronis is not known. Historical sequence of records indicates this mite to be native from either America or Africa. This species was originally described from Guerrero, Mexico (Keifer, 1965), where it was found at about the same time as in other American countries: Brazil (Robbs and Perachi, 1965), Colombia (Zuluaga and Sanchez, 1971) and Venezuela (Doreste, 1968). The mite symptoms had already been described in the latter three countries, before its original description, suggesting that A. guerreronis was already widespread in America at that time. The first report of A. guerreronis in Africa was made shortly after its first reports in America. It was reported in São Tomé and Principe Islands, Guinea Gulf, by Cabral and Carmona (1969) and in Benin in continental Africa by 
Mariau (1969). In general, a species has the highest morphometric and genetic variation in its place of origin. For instance, the geographic pattern of morphometric variation of A. guereronis observed throughout its distribution area support the hypothesis that this invasive mite originated from America.

Aceria guerreronis was only recently reported in Asia, in India and Sri Lanka (Sathiamma et al., 1998; Fernando et al., 2002). The similarity between the African and the Asian populations indicate their close genetic characteristics, suggesting that both populations had a common origin or that the Asian populations resulted from an introduction from Africa. It also corroborates with the prevailing idea and information that the mite introduction into Asia is recent, and the time for population establishment has not been sufficiently long to allow morphometric variability to develop. In addition, the similarity found among them also suggests that the gene pool introduced into Africa and Asia was rather restricted.

A conceivable limitation of the results obtained from African populations refers to the small number of samples (3) studied, for logistic reasons. A greater variability could be expected in the African continent by using a number of samples comparatively higher, leading to different conclusions from those reported in the present paper. However, such a limitation might have been partially compensated not only by the distance between the places where the samples were collected, but also because of the expected geographic isolation of those places in relation to each other. For instance, A. guerreronis may not be found in central Africa, considering that coconut, its main host, seems to be scarce or virtually absent in that area. Had the mite been present in that continent for a long time, those isolated populations would be expected to show higher morphometric variability. In any case, future studies will be more enlightening if considering larger numbers of samples from that continent.

The geographic proximity of the Asian populations (State of Kerala in southern India and Sri Lanka) does not seem to be a handicap, because it is a function of the presently limited distribution of $A$. guerreronis in that continent. In any case, it would also be worthwhile to include in future works samples from the Indian State of Tamil Nadu, where the mite has also been recently reported (Ramaraju et al., 2002).

It has been known that the morphology of Eriophyoidea mites may be related to their habitat structure. Boczek et al. (1984) observed significant variability of several morphometric characters of Aceria fockeui (Nalepa and Trouessart) collected from different Prunus species. Skoracka et al. (2002) reported morphological variability of Aceria schlechtendali (Nalepa) from different apple varieties. The latter authors also found significant differences between $A$. hystrix populations from different hosts. In the present study, the population of A. guerreronis collected from the growing tip of $S$. romanzoffiana, in California, was morphologically similar to the geographically closest populations (Mexico, Cuba and Venezuela) collected on coconuts.
The first report of A. guerreronis mites on growing tips of $S$. romanzoffiana was made recently (Ansaloni and Perring, 2002). Probably, the adoption time of $S$. romanzoffiana as a host has still not been sufficient for morphological differentiation to take place, considering that not only hosts but also plant organs attacked are rather different in this case.

The main variables affecting the observed results referred to opisthosoma and legs. Setae lengths were also important in the analyses, as already pointed out by Skoracka et al. (2002). Those authors showed that among the 11 characters that significantly discriminated populations of Aceria hystrix (Nalepa) from three host plants, four were setal lengths. In other earlier morphometric analyses of other Eriophyoidea, except for scapular setae (sc), setal lengths were not taken into account (Boczek et al., 1984; Huang et al., 1996). Those analyses were done taking into account basically body dimensions and locations and distances between bases of setae. Huang et al. (1996) argued that the length of some setae varies within single specimens and that the observed lengths may be affected by the way the specimen was prepared. It is suggested in the present paper that the adequate preparation of specimens, the use of a standard medium for all populations and the adoption of a criterion to deal with the normal variations of each specimen, as done in this paper, may render setal measurements suitable for use in morphometric analyses of Eriophyoidea.

The results of the present study allow some inferences related to the taxonomy of mites of that superfamily. Important characters used in the species descriptions of this group may vary considerably between populations and even between individuals of each population. In the case of A. guerreronis, the length of the scapular setae (sc) and of setae of the coxi-genital and opisthosomal regions; the distance and the number of microtubercles between ventral setae (d, e, f), body length and width, and the number of dorsal and ventral rings vary extensively between populations. The degree of variation observed in the morphological characters of the species indicates an expected degree of variation for mite species of this superfamily. It is possible that other mite species may differ in relation to the variability of each structure. Additional studies of this nature may be helpful in suggesting minimum numbers of specimens to be considered in taxonomic works of this group.

Acknowledgements - We are grateful to all collaborators from Benin, Brazil, Cuba, USA, India, Mexico, Sri Lanka, Tanzania and Venezuela for help in plant material and mite sample collection.The research work for this paper was accomplished at Setor de Zoologia Agricola, ESALQ-USP, Piracicaba, SP, Brazil as part of a thesis submitted by the senior author in partial fulfillment of the requirements for the Ph.D degree. We are grateful to $\mathrm{CNPq}$, Conselho Nacional de Desenvolvimento Científico e Tecnológico, Brazil, for the Ph.D fellowship.

\section{References}

AMRINE-JUNIOR, JW., DUCAN, GH, JONES, AT., GORDON, SC. and ROBERTS, IM. 1994. Cecidophyopsis 
mites (Acari: Eriophyidae) on Ribes spp. (Glossulariaceae). International Journal of Acarology, vol. 20, no. 3, p. 139-168.

ANSALONI, T. and PERRING, DTM. 2002. Biology of Aceria guerreronis Keifer on queen palms. In MORALESMALARACA, JB. and RIVAS, G. (Ed.). In XI International Congress of Acarology. Mexico: Universidad Nacional Autónoma de Mexico. p. 145.

BOCZEK, J., ZAWADZKI, W. and DAVIS, R. 1984. Some morphological and biological differences in Aculus fockeui (Nalepa and Trouessart) (Acari: Eriophyidae) on various host plants. International Journal of Acarology, vol. 10, no. 2, p. 81-87.

BOOKSTEIN, FL., CHERNOFF, B., ELDER, RL., HUMPHRIES, JM., SMITH, GR. and STRAUSS, RE. 1985. Morphometrics in evolutionary biology. Philadelphia: Academy of Natural Sciences of Philadelphia. 277 p. Special Publication, no. 14.

CABRAL, RVG. and CARMONA, DMM. 1969. Aceria guerreronis Keifer (Acarina: Eriophyidae), uma espécie nova para S. Tomé e Príncipe Portugaliae. Acta Biológica, vol. 10, no. 3-4, p. 353-358.

DORESTE, SE. 1968. El ácaro de la flor del cocotero (Aceria guerreronis Keifer) en Venezuela. Agronomia Tropical, vol. 18, no. 3, p. 370-386.

FERNANDO, LCP., WICKRAMANANDA, IR. and ARATCHIGE, NS. 2000. Status of coconut mite, Aceria guerreronis in Sri Lanka. In FERNANDO, LCP., MORAES, GJ. and WICKRAMANANDA, IR. (Ed.). Proceedings of the International Workshop on Coconut Mite (Aceria guerreronis). Lunuwila: Coconut Research Institute. p. 1-8.

HUANG, KW., HUANG, T. and WANG, CF. 1996. Morphometric analysis between Spinacus pagonis Keifer and its affined species (Acarina: Eriophyidae). Zoological Studies, vol. 35, no. 3, p. 178-187.

KEIFER, HH. 1965. Eriophyid Studies B-14. Sacramento: California Department of Agriculture. 20 p.

LEBRUN, P., GRIVET, L. and BAUDOIN, L. 1998. Dissemination et domestication du cocotier a la lumière des marqueurs RFLP. Plantations Recherche Developpement, vol. 5, no. 1, p. 233-245.

MARIAU, D. 1969. Aceria guerreronis Keifer: récent ravageur de la cocoteraie dahoméenne. Oléagineux, vol. 24. no. 4, p. 269-272.
MOORE, D. and HOWARD, FW. 1996. Coconuts. In LINDQUIST, EE., SABELIS, MW. and BRUIN, J. (Ed.). Eriophyoid mites: their biology, natural enemies and control. Amsterdam: Elsevier. p. 561-570.

MORAES, GJ. and ZACARIAS, MS. 2000. Use of predatory mites for the control of eriophyid mites. In FERNANDO, LCP., MORAES, GJ. and WICKRAMANANDA, IR. (Ed.). Proceedings of the international workshop on coconut mite (Aceria guerreronis). Lunuwila: Coconut Research Institute. p. $78-88$.

NAVIA, D., MORAES, GJ., RODERICK, G. and NAVAJAS, M. 2005. The invasive coconut mite Aceria guerreronis (Acari: Eriophyidae): origin and invasion sources inferred from mitochondrial (16S) and nuclear (ITS) sequences. Bulletin of Entomological Research, vol. 95, no. 6, p. 505-516.

PERSLEY, GJ. 1992. Replanting the tree of life: towards an international agenda for coconut palm research. Wallingford: CAB International. $156 \mathrm{p}$.

RAMARAJU, K., NATARAJAN, K., SUNDARA-BABU, PC., PALANISAMY, S. and RABINDRA, RJ. 2002. Studies on coconut eriophyid mite, Aceria guerreronis Keifer in Tamil Nadu, India. In FERNANDO, LCP., MORAES, GJ. and WICKRAMANANDA, IR. (Ed.). Proceedings of the International Workshop on Coconut Mite (Aceria guerreronis). Lunuwila: Coconut Research Institute. p. 13-31

REIS, SF. 1988. Morfometria e estatística multivariada em biologia evolutiva. Revista Brasileira de Zoologia, vol. 5, no. 4, p. $571-580$.

ROBBS, CF. and PERACCHI, AL. 1965. Sobre a ocorrência de um ácaro prejudicial ao coqueiro (Cocos nucifera L.). In 9 Anais Reunião Fitossanitária. Rio de Janeiro: SDSV. p. 65-70.

SAS Institute, 1990. SAS/STAT User's Guide. Version 6. 4 ed. Cary: SAS Institute.

SATHIAMMA, B., RADHAKRISHNAN NAIR, CP. and KOSHI, CP. 1998. Outbreak of a nut infesting eriophyid mite, Eriophyes guerreronis $(\mathrm{K})$ in coconut plantations in India. Indian Coconut Journal, vol. 29, no. 2, p. 1-3.

SKORACKA, A., KUCZYNSKI, L. and MAGOWSKI, W. 2002. Morphological variation in different host populations of Abacarus hystrix (Acari: Prostigmata: Eriophyoidea). Experimental and Applied Acarology, vol. 26, no. 3-4, p. $187-193$.

ZULUAGA, CI. and SÁNCHEZ, AP. 1971. La roña o escoriación de los frutos del cocotero (Cocos nucifera L.) en Colombia. Acta Agronómica, vol. 21. no. 3, p. 133-139. 